$2-2016$

\title{
Eliminating Rivals, Managing Rivalries: a Comparison of Robert Mugabe and Kenneth Kaunda
}

Stephen McLoughlin

Griffith University

Maartje Weerdesteijn

Tilburg University

Follow this and additional works at: https://digitalcommons.usf.edu/gsp

\section{Recommended Citation}

McLoughlin, Stephen and Weerdesteijn, Maartje (2016) "Eliminating Rivals, Managing Rivalries: a Comparison of Robert Mugabe and Kenneth Kaunda," Genocide Studies and Prevention: An International Journal: Vol. 9: Iss. 3: 116-136.

DOI:

http://dx.doi.org/10.5038/1911-9933.9.3.1318

Available at: https://digitalcommons.usf.edu/gsp/vol9/iss3/10

This Articles is brought to you for free and open access by the Open Access Journals at Digital Commons @ University of South Florida. It has been accepted for inclusion in Genocide Studies and Prevention: An International Journal by an authorized editor of Digital Commons @ University of South Florida. For more information, please contact digitalcommons@usf.edu. 
Eliminating Rivals, Managing Rivalries: a Comparison of Robert Mugabe and Kenneth Kaunda

\section{Acknowledgements}

Authors are listed in alphabetical order. 


\title{
Eliminating Rivals, Managing Rivalries: A Comparison of Robert Mugabe and Kenneth Kaunda
}

\author{
Stephen McLoughlin \\ Griffith University \\ Queensland, Australia
}

\author{
Maartje Weerdesteijn \\ Tilburg University \\ Tilburg, Netherlands
}

\begin{abstract}
This article seeks to explore the role that leadership plays in both the perpetration and avoidance of mass atrocities. Many scholars have argued that leadership is pivotal to the outbreak of such violence but there is almost no scholarship which explores the role that political leaders play in mitigating or aggravating the risk of atrocities over time. Why is it that mass atrocities occur in some places but not in others, despite the existence of similar risk factors? By conducting a comparative analysis of Robert Mugabe of Zimbabwe and Kenneth Kaunda of Zambia, this paper investigates the impact that the strategies of each leader had on the risk of mass atrocities. Both countries share similar colonial backgrounds, and display comparable structural risk factors commonly associated with genocide and other mass atrocities. Both Kaunda and Mugabe were key leaders in their countries' liberation struggles, and both leaders played pivotal roles during the crucial formative years of independence. Yet the two countries have taken dramatically different paths - while Zambia has remained relatively stable and peaceful, Zimbabwe has experience mass violence and repression.
\end{abstract}

Keywords: Robert Mugabe, Kenneth Kaunda, leadership, structural risk factors.

Kenneth Kaunda of Zambia and Robert Mugabe of Zimbabwe share very similar histories, but their struggles for independence, and stewardship as post-colonial inaugural leaders left remarkably different imprints on their countries. Kaunda was born into Northern Rhodesia, and Mugabe, Southern Rhodesia-both British protectorates at the time. Both became politically conscious after these two protectorates-along with Nyasaland-merged to form the Central African Federation. Both men were imprisoned by British colonial administrators, and both were at the forefront of long liberation struggles. Yet these two leaders steered their countries in very different directions. Zambia is a peaceful, stable and democratic country after Kaunda conceded to multi-party elections in 1991. By contrast, Zimbabwe remains bogged down by Mugabe's entrenched and violent regime since the country gained independence in 1980; its population continues to suffer the effects of pervasive corruption and poverty, and at times various groups have been the target of state-perpetrated atrocities. ${ }^{1}$ Why is it that under the charge of these two leaders, Zimbabwe experienced mass atrocities, while Zambia did not?

Theoretical claims in the scholarship on comparative genocide studies fail to adequately explain this difference. Research into the causes of genocide and other mass atrocities focus overwhelmingly on positive cases - cases where such violence has occurred. While such studies have made valuable contributions to our understanding of both long-term risk and escalating factors, one key blind spot remains. Currently there is very little research that investigates why mass atrocities do occur in some countries where risk factors are present while they do not occur in others. ${ }^{2}$ One consequence of this is that local and national processes of effective risk mitigation - and prevention - are poorly understood. UN Secretary General Ban Ki-moon pointed out this limitation in a 2009 report on the Responsibility to Protect: "More research and analysis are needed

\footnotetext{
${ }^{1}$ We define atrocities as widespread and systematic attacks on unarmed civilians, usually codified as genocide, crimes against humanity, war crimes and ethnic cleansing.

${ }^{2}$ Two exceptions are Mayersen, Deborah and Stephen McLoughlin. 2011. "Risk and Resilience to Mass Atrocities in Africa: A Comparison of Rwanda and Botswana." Journal of Genocide Research Vol. 12, No. 3, 247-269; and Straus, Scott 2012.

"Retreating from the Brink: Theorizing Mass Violence and the Dynamics of Restraint." Perspectives on Politics Vol. 10, No. 2, 343-62.
}

Stephen McLoughlin and Maartje Weerdesteijn, "Eliminating Rivals, Managing Rivalries: A Comparison of Robert Mugabe and Kenneth Kaunda" Genocide Studies and Prevention 9, 3 (2016): 116-136. @2016 Genocide Studies and Prevention. 
on why one society plunges into mass violence while its neighbours remain relatively stable..."3 To better understand this critical question, it is necessary to compare cases that were similar in risk, yet different in outcome.

At independence, both Zambia and Zimbabwe contained long-term risk factors associated with mass atrocities. Both had pronounced horizontal inequalities between black and white populations; ${ }^{4}$ both experienced growing political tensions based on ethno-linguistic difference, ${ }^{5}$ and both leaders developed authoritarian tendencies to consolidate their power. ${ }^{6}$ Zambia had the added pressure of one province repeatedly calling for secession, ${ }^{7}$ while Zimbabwe bore the scars of a recently ended civil war. ${ }^{8}$

This article seeks to account for the dramatically different paths of these two neighbouring countries by conducting a comparative analysis of the leadership Robert Mugabe and Kenneth Kaunda. We argue that although both countries share a similar past and were initially comparable in terms of risk factors, the two countries ultimately followed different paths due the influence of their inaugural leaders. The two leaders differed markedly in their rhetoric, ideology and strategies. We investigate the impact that the strategies of each leader had on the risk of mass atrocities and in doing so we will focus on the role of the leader in either mitigating or aggravating this risk in the formative years of their rule. ${ }^{9}$

The article will unfold as follows. First, we present an overview of the relevant literature and highlight the remaining gaps therein. Second, we provide a brief introduction into the background of the leaders. Third, we analyse the risk factors at independence, and investigate the ways each leader dealt with these risk factors, through choices made and strategies adopted. Fourth, we will assess whether there are any other factors to which the different levels of violence in the two countries might be attributed. Finally, we will conclude by arguing the leader may indeed be seen as a crucial determinant of whether risk factors are actually transformed into mass atrocities. We conduct a qualitative analysis of mostly secondary sources. While we acknowledge the limitations of such an approach, we argue that that such an approach is sufficient in proposing a research agenda that focuses on the role of leaders in both positive and negative cases. Field-based researchparticularly based on interviews of elites who were close to both leaders during the early years of

\footnotetext{
${ }^{3}$ Ban Ki-moon. 2009 “Implementing the Responsibility to Protect." A/63/677. New York: United Nations, 10-11.

${ }^{4}$ For the relationship between horizontal inequality and risk, see Stewart, Frances. 2008. "Horizontal Inequalities and Conflict: An Introduction and Some Hypotheses." In Horizontal Inequalities and Conflict: Understanding Group Violence in Multi-ethnic Societies. Edited by Frances Stewart. New York: Palgrave Macmillan, and Nafziger, E. Wayne and Juha Auvinen. 2002. "Economic Development, Inequality, War and State Violence." World Development Vol. 30, No. 2, 153-163.

${ }^{5}$ For more on identity-based cleavages, see Harff, Barbara. 2003. "No Lessons Learned from the Holocaust? Assessing Risks of Genocide and Political Mass Murder since 1955." American Political Science Review Vol. 12, No. 1, 57-73; and Stanton, Gregory. 2004. "Could the Rwandan Genocide have been Prevented?" Journal of Genocide Research Vol. 6, No. 2, 211-228.

${ }^{6}$ On the relationship between regime type and mass atrocities, see Krain, Matthew. 2000. "Democracy, Internal War, and State-Sponsored Mass-Murder." Human Rights Review Vol. 1, No. 3, 40-48; Fein, Helen. 1995. “More Murder in the Middle: Life-Integrity Violations and Democracy in the World, 1987." Human Rights Quarterly Vol. 17, No. 1, 170-91; Regan, Patrick M. and Errol A. Henderson. 2002. "Democracy, Threats and Political Repression in Developing Countries: Are Democracies Internally Less Violent?" Third World Quarterly Vol. 23, No.1, 119-136; Rummel, Rudolph J. 1994. "Power, Genocide and Mass Murder." Journal of Peace Research Vol. 31, No. 1, 1-10.

${ }^{7}$ Contested secession can often provoke a political crisis which leads to conflict characterized by mass atrocities. The secessionist conflicts in Georgia (Abkhazia, South Ossetia), Sri Lanka, Bangladesh (East Pakistan) and Chechnya were marked by widespread and systematic violence against civilians.

${ }^{8}$ On the links between war and (repeated) atrocities see Shaw, Martin. 2007. "The General Hybridity of War and Genocide." Journal of Genocide Research Vol. 9, No. 3, 461-73; Fein, Helen. 1993. "Accounting for Genocide after 1945: Theories and Some Findings." International Journal on Group Rights Vol. 1, No. 2, 79-106; Alvarez, Alex. 2001. Governments, Citizens, and Genocide: A Comparative and Interdisciplinary Approach. Bloomington: Indiana University Press; Harff, Barbara. 2003. "No Lessons Learned from the Holocaust? Assessing Risks of Genocide and Political Mass Murder since 1955." American Political Science Review Vol. 12, No. 1, 57-73; and Midlarsky, Manus I. 2005. The Killing Trap: Genocide in the Twentieth Century. Cambridge: Cambridge University Press, 43-44.

${ }^{9}$ In relation to the impact that leaders and elites play in the causal path to mass killing, see Valentino, Benjamin. 2004. Final Solutions: Mass Killing in the Twentieth Century. Ithaca: Cornell University Press. Valentino focuses solely on elite strategies that precede episodes of mass killing, whereas our analysis looks at the interaction between leadership strategies and structural risk factors associated with mass atrocities.
} 
independence-would go further in accounting for the behaviour and decision-making of Mugabe and Kaunda, and would potentially complement and extend the claims we make in this article.

A Framework for Understanding the Impact of Leaders on Risk Escalation and Risk Mitigation An approach to understanding the impact that leaders have in both the perpetration and avoidance of mass atrocities needs to consider the relationship between individual leaders and broader structural risk factors. We base our frame of analysis of these two leaders on three premises. First, theories on the causes of mass atrocities focus overwhelmingly on structural factors, largely overlooking the impact that leaders have. Second, scholarly research that investigates the relationship between leadership and power-particularly the abuse of power-does not consider how such abuse increases the risk of atrocity crimes. Third, to date we have a limited understanding of why some countries-containing risk-experience atrocities while others with comparable risk do not. Embedded in this is a lack of understanding of the role that leaders might play in aggravating risk, or mitigating risk, and thus preventing mass atrocities. If leaders play an important role here-as we believe they do-an analytical framework is necessary for developing a more substantive account of their impact on processes of risk escalation and risk mitigation.

Scholars theorizing on the causes of mass atrocities focus overwhelmingly on structural factors. Key risk factors include: politicised identity-based divisions,; ${ }^{10}$ horizontal inequalities, ${ }_{i}^{11}$ prior atrocities, ${ }^{12}$ authoritarian regimes with exclusionary ideologies, ${ }^{13}$ and an unstable neighbourhood. ${ }^{14}$ By contrast, there is very little scholarship that focuses on leadership and individual agency. Although historical studies of single events like the Holocaust do inevitably talk about leadership, ${ }^{15}$ individual agency in general is under-theorised in the scholarship on genocide and other atrocities. One exception is Valentino, who argues that an examination of the strategies and policies of political elites should be the starting point in investigating the causes of political mass violence. In doing so, he argues that macro-level social structures tell us little, given what he claims is their tenuous causal links to violent outcomes. While there is indeed no direct causal link between structural risk factors and outcomes of atrocity crimes, ${ }^{16}$ such crimes are rarely, if ever, planned and ordered by elites in the absence of such factors. Other scholars have argued that the choices that leaders make is very much contingent upon the contextually specific factors of risk already in existence, justifying the need to understand the relationship between structural risk and the decisions, attitudes and actions of leaders. ${ }^{17}$

In the scholarship that does focus explicitly on leadership and power, and the abuses of power, there is very little engagement with the scholarship on the causes of mass atrocities more generally. Byman and Pollack, for example, focus on power of leaders to shape events more broadly. They argue that International Relations theory has overlooked the influence that leaders have in influencing key international events and turning points, highlighting that international scholars overwhelmingly opt for structural arguments to explain change in the international system. Using three cases to demonstrate the gravitas that political leaders have played in shaping events, they highlight a need for better understanding the impact of leaders on such violent phenomena as

\footnotetext{
${ }^{10}$ Stanton, "Could the Rwandan Genocide have been Prevented?" 213-214; Kuper, Leo. 1981. Genocide: Its Political Use in the Twentieth Century. Middlesex: Penguin Books, 53-55; Fein, "Accounting for Genocide," 82.

${ }^{11}$ Stewart, "Horizontal Inequalities"; Langer, "When do Horizontal Inequalities Lead to Conflict?".

${ }^{12}$ Harff, "No Lessons Learned", 63.

${ }^{13}$ Ibid; Krain, "Democracy, Internal War and State-Sponsored Murder"; Rummel, "Power, Genocide and Mass Murder".

${ }^{14}$ Goldstone, Jack A. and Jay Ulfelder. 2004. "How to Construct Stable Democracies." The Washington Quarterly Vol. 28, No. 1, 13-14.

${ }^{15}$ See, for example, Chandler, David P. 1999. Brother Number One: A Political Biography of Pol Pot. Bankok: Silkworm Books; Kershaw, Ian. 1998. Hitler: A Biography. New York: W.W. Norton \& Company Inc.

${ }^{16}$ See Harff, "No Lessons Learned."

${ }^{17}$ See, for example, Byman, Daniel. 2002. Keeping the Peace: Lasting Solutions to Ethnic Conflicts. Baltimore: John Hopkins University Press, 34; Goldhagen, Daniel Jonah. 2009. Worse Than War: Genocide, Eliminationism, and the Ongoing Assault on Humanity. New York: Public Affairs, 74-84; Staub, Ervin 2010. Overcoming Evil: Genocide, Violent Conflict and Terrorism. Oxford: Oxford University Press, 174.
} 
ethnic conflict and mass killing. ${ }^{18}$ Other studies that have theorised on the nature and impact of harmful leadership, include for instance the work of Post, who focuses on the psychology of destructive leaders arguing, through a variety of case studies, that "clear actor specific models of their psychology and decision making" are essential to counter these leaders effectively. ${ }^{19}$ He does not however engage with the literature identified above on the structural preconditions which may lead to mass atrocities specifically. Padilla et al. set up a three-tiered framework called the Toxic Triangle in order to understand how and why leaders become destructive. Their Triangle considers the susceptibility of followers, and the manner in which negative and hateful ideologies are used by individual leaders to cement power, but does not consider how such triangles may lead to mass atrocities, as distinct from repressive environments and does not engage with literature on genocide and mass atrocities. While their claims allude to some of the preconditions associated with mass atrocities (such as ideologies of hate, instability and upheaval), they do not consider how such destructive tendencies lead to the perpetration of mass atrocities. ${ }^{20}$ Finally, Wriggins offers a comprehensive theoretical approach to understanding what post-colonial leaders do to consolidate power and strengthen influence. It discusses various forms of intimidation that leaders have adopted, noting briefly the most extreme tactic of liquidation, whereby an opponent may disappear $(1969,159-179){ }^{21}$ the use of more collective violent tactics to cement power are not considered. How and why leaders use their power to commit mass atrocities, or to mitigate the risk associated with such violence is profoundly understudied. ${ }^{22}$

Also poorly understood is why it is that some countries experience atrocities while others do not, despite comparable risk factors present. UN Secretary-General acknowledged this in relation to mass atrocities in his 2009 report, "Implementing the Responsibility to Protect." In a recent report, he further elaborated on this gap by proposing a framework for understanding national sources of resilience in the mitigation of risk. ${ }^{23}$ This represents the first framework within the UN that considers not only risk, but the sources of risk mitigation in the context of mass atrocity prevention. Although his identification of six sources of resilience mapped out the varied processes of risk mitigation, it focussed overwhelmingly on structural factors. Overlooked in this report is the role that leadership can play in aggravating risk, or strengthening a country's resilience. While there has been some progress in recent years in better understanding why atrocities are committed in some places but not in others, the impact that leadership has on different outcomes remains poorly understood.

This is despite the acknowledgement of many genocide scholars that leadership is crucial. Hamburg, for instance, stresses that "genocides are precipitated by leaders of extremist and violent political or religious sects or regimes who take advantage of predisposing elements and cultural myths, then skilfully work on them to incite their population to genocide." ${ }^{24}$ Speaking of the causal

\footnotetext{
${ }^{18}$ Byman, Daniel L. and Kenneth M. Pollack. 2001. "Let Us Now Praise Great Men: Bringing the Statesman Back In." International Security Vol. 25, No. 4, 146.

${ }^{19}$ Post, Jerrold M. 2004. Leaders and Their Followers in a Dangerous World: The Psychology of Political Behavior. Ithaca: Cornell University Press, 61.

${ }^{20}$ Padilla, Art, Robert Hogan and Robert B. Kaiser. 2007. “The Toxic Triangle: Destructive Leaders, Susceptible Followers and Conducive Environments." The Leadership Quarterly Vol. 18, No. 3, 176-194.

${ }^{21}$ Wriggins, W. Howard. 1969. The Ruler's Imperative: Strategies for Political Survival in Asia and Africa. New York: Columbia University Press, 159-179.

${ }^{22}$ Other work which looked at destructive leaders, or abusive dictatorial rule but does not engage explicitly with the literature on structural preconditions to analyse how mass atrocities occur, includes de Vries, Kets. 2004. Lessons on Leadership by Terror: Finding Shaka Zulu in the Attic. Cheltenham: Edward Elgar Publishing Limited; Chirot, Daniel. 1994. Modern Tyrants: The Power and Prevalence of Evil in Our Age. New York: The Free Press; Moghaddam, Fathali M. 2013. The Psychology of Dictatorship. Washington, American Psychological Association; Ezrow, Natasha and Erica Frantz. 2011. Dictators and Dictatorships: Understanding Authoritarian Regimes and their Leaders. New York: Continuum, 2011; de Mesquita, Bruce Bueno and Alastair Smith. 2011. The Dictator's Handbook: Why Bad Behaviour is Almost Always Good Politics. New York: Public Affairs; and Jackson, Robert H. and Carl G. Rosberg. 1982. Personal Rule in Black Africa: Prince, Autocrat, Prophet, Tyrant. Berkeley, University of California Press.

${ }^{23}$ Ban Ki-moon. 2013. “The Responsibility to Protect: State Responsibility and Prevention.” A/67/929-S/2013/399, 8-11.

${ }^{24}$ Hamburg, David. 2008. Preventing Genocide: Practical Steps toward Early Detection and Effective Action. Boulder: Paradigm Publishers.
} 
paths to ethnic conflict, Byman argues that elites can have "agendas of their own that lead to conflict or increase the scope and scale of existing tension." ${ }^{25} \mathrm{He}$ also points out that elites "can dampen conflict as well." 26

If leadership is a key ingredient in both the perpetration and prevention of mass atrocities, then a better understanding of this dimension would contribute to the scholarship on the causes of mass atrocities, as well as contribute to the growing literature on the ways that risk can be mitigate and resilience strengthened in countries. Our study of Kaunda and Mugabe aims to help address some of these gaps. First, it addresses the question of why it is that atrocities occur in some countries but not in others, despite risk. Second, it focuses on each country's inaugural leader, and by doing so we consider the role of individual agency in the relationship between risk and resilience.

Where does the role of leadership fit in a broader understanding of the causes and prohibitors of mass atrocities? A four-tiered framework provides an analytical lens to better understand this question, incorporating the following:

1. The presence of structural risk factors (as outlined above);

2. Evidence of crisis or upheaval that increases the salience of these risk factors;

3. An examination of the role of political leaders in either aggravating or mitigating risk associated with mass atrocities.

4. A consideration of other factors that could have an impact on the escalation or mitigation of risk.

The first two factors create a benchmark for selection of both positive and negative cases (that is cases where the dependent variable is different). Zimbabwe's selection as a positive case is on the basis that mass atrocities were committed there between 1980 and 1988, through the torture and massacring of members of the Ndebele minority group. Approximately 20,000 Ndebele speakers were massacred by government forces ${ }^{27}$ eclipsing the violence that had accompanied the war of liberation prior to independence. Zambia's selection is on the basis that it contained some structural risk factors, and had recently experienced the upheaval of decolonisation. On this basis, we argue that in the first decade of independence in Zambia, mass atrocities were possible. The third tier casts an analytical lens over the decisions the leader made that led to different outcomes. This framework of analysis provides a more substantive investigation of the role of leadership in relation to the commission of mass atrocities, presenting an opportunity. The fourth tier excludes alternative explanations that may have led to this outcome.

At independence, the countries of these two leaders contained sufficient similarities to justify the comparative analysis. They were both former British colonies, which, between 1953 and 1963 were ruled as a single administrative bloc, known as the Central African Federation. At the cusp of independence, both countries had powerful European communities that controlled most of each territory's wealth, creating profound economic inequalities. While it is clear that Zimbabwe's European community was larger than Zambia's - about 5 percent of the population compared to 3 percent in Zambia, the white minority in both territories controlled the vast majority of the wealth, including the best farmland, and the resource extraction industry. ${ }^{28}$ At independence, both countries' nascent democracies were characterised by serious factional divisions based on ethno-linguistic difference. ${ }^{29}$ It is also true that both countries experienced very different liberation struggles. In Zambia, a predominantly non-violent campaign in the 1950s and early 1960s preceded

\footnotetext{
${ }^{25}$ Byman, Daniel. 2002. Keeping the Peace: Lasting Solutions to Ethnic Conflicts. Baltimore: John Hopkins University Press, 34.

${ }^{26}$ Byman, Keeping the Peace, 25.

${ }^{27}$ Catholic Commission for Justice and Peace \& Legal Resources Foundation (CCJPZ \& LRF). 1999. "Breaking the Silence, Building True Peace: A Report on the Disturbances in Matabeleland and the Midlands 1980-1988," 471.

${ }^{28}$ Good, Robert C. 1973. U.D.I.: The International Politics of the Rhodesian Rebellion. Princeton: Princeton University Press, 15-16; Roberts, Andrew. 1976. A History of Zambia. London: Heinemann, 212-213.

${ }^{29}$ Posner, Daniel N. 2003. "The Colonial Origins of Ethnic Cleavages: The Case of Linguistic Divisions in Zambia." Comparative Politics Vol. 35, No. 2, 129; Roberts, Zambia, 241; Ranger, Terence. 1982. The Invention of Tribalism in Zimbabwe. Gweru: Mambo Press.
} 
a largely peaceful transition to self-rule. By contrast, in Rhodesia, the movement toward majorityrule independence was hijacked by Ian Smith's Universal Declaration of Independence in 1965, which heralded 15 more years of repressive white-minority rule. This became the catalyst for an increasingly violent struggle, which escalated into a protracted civil war. ${ }^{30}$ Yet this difference should not rule out the value in comparing the two leaders during the early years of independence. To rule out such a comparison on this basis risks making the presumption that at independence, atrocities were inevitable in Zimbabwe, and impossible in Zambia. Neither situation was true. In fact, in 1980, Zimbabwe was widely regarded as having a bright future-once the war was over, most were hopeful for Zimbabwe's future at the time. ${ }^{31}$ Moreover, in Zambia the prospect of a cohesive, unified and stable future was far from certain. As this analysis will show, almost immediately the spoils of government were being fought over by various factions with the governing party and amongst opposition parties - factions along ethno-linguistic lines. ${ }^{32}$ What we aim to do with this analysis, is to contribute to an emerging research agenda within comparative genocide studies, which seeks to better understand why atrocities occur in some places but not in others; or to compare "what goes wrong" with "what goes right", in relation to mass atrocity risk.

Given that this analysis utilizes a comparison between one positive case (Zimbabwe) and one negative case (Zambia), questions about the basis of negative case selection are worth further reflection. Under what conditions are negative cases justified? Is it only justified in cases where the dependent variable was imminent, or highly likely? We use Mahoney and Goertz's possibility principle. They argue that negative cases should be selected on the basis of possibility, rather than likelihood or imminence. According to Mahoney and Goertz, a negative case is deemed possible when it fulfils two criteria - the first is that they share at least one independent variable associated with the dependent variable; and the second is that a case should be excluded if it contains conditions that make the outcome impossible. ${ }^{33}$ Regarding the first principle, Zambia fulfils this requirement through the presence of risk factors discussed above. To fulfil the second principle, we utilize Mahoney and Goertz' discussion of genocide as an illustration. Using genocide scholar Barbara Harff's work, they identify the "absence of upheaval" as fulfilling the second-without upheaval, genocides, politicides and other forms of mass violence rarely, if ever occur. ${ }^{34}$ Harff defines upheaval as "an abrupt change in the political community," caused by various factors including war, regime change and decolonization. ${ }^{35}$ Zambia's recent decolonization (in the period under study) fulfils the second principle.

\section{Background of Leaders}

While Kaunda and Mugabe steered their countries to dramatically different fates, an overview of their lives reveals remarkable similarities. Both leaders were influenced by their religious upbringing. Kaunda's religious instruction came initially from his father, who himself was a teacher and missionary from Nyasaland. ${ }^{36}$ Mugabe was raised by his devout Catholic mother after his father abandoned the family when he was still a child. ${ }^{37}$ While both were initially expected to become clerics, they chose to become teachers and political activists instead. ${ }^{38}$

\footnotetext{
${ }^{30}$ Maxey, Kees. 1975. The Fight for Zimbabwe: The Armed Conflict in Southern Rhodesia since UDI. London, Rex Collings; Wills, A. J. 1985. An Introduction to the History of Central Africa: Zambia, Malawi and Zimbabwe. Oxford University Press: Oxford.

${ }^{31}$ Sachikonye, Lloyd M. 2002. "Whither Zimbabwe? Crisis and Democratisation." Review of African Political Economy Vol. $91,13$.

${ }^{32}$ Molteno, Robert. 1974. "Cleavage and Conflict in Zambian Politics: A Study in Sectionalism." In Politics in Zambia. Edited by William Tordoff. Manchester: Manchester University Press.

${ }^{33}$ Mahoney, James and Gary Goertz. 2004. "The Possibility Principle: Choosing Negative Cases in Comparative Research." American Political Science Review Vol. 98, No. 4, 657-658.

${ }^{34}$ Mahoney and Goertz, "The Possibility Principle," 658.

${ }^{35}$ Harff, “No Lessons Learned," 62.

${ }^{36}$ Kaunda, Kenneth. 1962. Zambia Shall be Free. London: Heinemann, 5.

${ }^{37}$ Moorcraft, Paul. 2011. Mugabe's War Machine: Saving or Savaging Zimbabwe? Barnsley: Pen \& Sword Military, 44; Meredith, Martin. 2002. Our Votes, Our Guns: Robert Mugabe and the Tragedy of Zimbabwe. New York: Public Affairs, 19.

${ }^{38}$ Holland, Heidi. 2008. Dinner with Mugabe: The Untold Story of a Freedom Fighter who Became a Tyrant. London: Penguin
} 
Both leaders joined opposition movements that sought to end white minority rule in their respective countries, Northern Rhodesia (later Zambia) and Southern Rhodesia (later Zimbabwe) which were joined together in 1950 to form the Central African Federation along with Nyasaland (later Malawi). In Northern Rhodesia, as the 1950s progressed, Kaunda and the ANC organized boycotts against white-owned businesses that had engaged in the discriminatory treatment of Africans. ${ }^{39}$ This evolved into a struggle to end the CAF, and to gain independence for Zambia, principally through strategies of non-violent disobedience. ${ }^{40}$

In Zimbabwe, a moderate black opposition party was launched in 1957, headed by Joshua Nkomo. ${ }^{41}$ Mugabe was not involved in politics until 1960 when friends persuaded him to become active and he would hold is first speech in front of thousands of other protestors. ${ }^{42}$ Within the opposition movement, which by that time had become known as the Zimbabwe African People's Union (ZAPU), Nkomo's tactics were criticised for being too compromising and not making enough headway. Mugabe was among those critics and became part of the breakaway faction the Zimbabwe African National Union (ZANU), which believed attacks on whites and their property were necessary. ${ }^{43}$ Initially the differences between the two groups seemed relatively minor but they were magnified as they drew support from different ethno-linguistic groups and were backed by different countries. ${ }^{44}$

Frustrated with the political struggle, both parties eventually developed military wings; ZAPU relied on ZIPRA to fight their battles and ZANU on ZANLA. ${ }^{45}$ Animosity among the groups resulted in violent gang warfare. ${ }^{46}$ In the first years, before the unilateral declaration of independence (UDI), there were also occasional outbursts of violence against the white population, but after the UDI guerrilla attacks became more frequent and a guerrilla war ensued in which the nationalist parties fought Smith's white minority regime and each other. ${ }^{47}$ After having been imprisoned for ten years, Mugabe became the de facto commander in chief in the final years when it became clear the Rhodesians would ultimately loose. ${ }^{48}$

Kaunda too, spent time in prison, and came to head a more militant breakaway faction. His first imprisonment-for two months-occurred in 1955, under the charge of distributing "prohibited publication". ${ }^{49}$ A power struggle with the ANC's leader, Harry Nkumbula, in 1958, resulted in Kaunda and other leading members leaving and forming a new organization called the Zambian African National Congress (ZANC). ${ }^{50}$ ZANC distinguished itself from the ANC by adopting more militant ideas-they decried the ANC's willingness to negotiate with the government, and established themselves by staging rallies throughout the countrysiderallies that frequently contained inflammatory language and provoked disturbances against white settlers and colonial authorities. The CAF government banned the ZANC in 1959, and

Books, 11; Moorcraft, Mugabe's War Machine, 44. Kaunda's training as a teacher was initially a first step towards becoming a cleric, but his political activism soon took over.

${ }^{39}$ Burdette, Marcia M. 1988. Zambia: Between Two Worlds. Boulder: Westview Press, 30; Kaunda, Zambia Shall Be Free, 73-74.

${ }^{40}$ Kaunda, Zambia Shall Be Free, 60-80.

${ }^{41}$ The opposition party started out as the African National Congress (ANC), until this was banned in 1959, when it became the National Democratic Party (NDP), and when this was banned in 1961, the movement would become known as the Zimbabwe African People's Union (ZAPU) and when that was banned, for a while was called Peoples Caretaker Council (PCC) but would continue to be known as ZAPU (Meredith 2002, 24-32).

${ }^{42}$ Meredith, Our Votes, Our Guns, 26-27.

${ }^{43}$ Ibid, 28-32; Chan, Stephen. 2003. Robert Mugabe: a Life of Power and Violence. London: I.B. Taurus, 6; Maxey, The Fight for Zimbabwe, 5.

${ }^{44}$ Meredith, Our Votes, Our Guns, 32-33; Moorcraft, Mugabe's War Machine, 46.

${ }^{45}$ Chan, Robert Mugabe, 7.

${ }^{46}$ Meredith, Our Votes, Our Guns, 33.

${ }^{47}$ Maxey, The Fight for Zimbabwe, 54-64; Moorcraft, Mugabe's War Machine, 35-36.

${ }^{48}$ Moorcraft, Mugabe's War Machine, 47-48.

${ }^{49}$ The publication in question was a copy of the British anti-colonial magazine, Africa and the Colonial World.

${ }^{50}$ Roberts, Zambia, 220. 
jailed many of its leaders, including Kaunda. ${ }^{51}$ When UNIP was formed in the wake of ZANC's prohibition, Kaunda-upon his release in 1960-continued to define the movement by calling for an instant end to the Federation, and by promoting both non-racialism and pan-Africanism. ${ }^{52}$ While Kaunda stressed the need for non-violence, he did not shy away from tactics that promoted inter-racial antagonism, and on occasion, violence. A. J. Wills pointed out that Kaunda's "inflammatory speeches led to a growing number of disturbances" in 1960, ${ }^{53}$ including the blowing up of bridges, and the attacking of buses and schools as part of UNIP-instigated intimidation. Kaunda advocated non-violence, but also promised a swift end to white rule, and a rapid rebalancing of economic inequities. These populist messages had broad appeal, and enabled Kaunda to become the dominant leader in the liberation struggle.

While violence remained limited in Zambia, in Zimbabwe the rivalry between ZANU and ZAPU and their struggle against Ian Smith's repressive white minority rule grew ever more violent. Within the liberation struggle Mugabe chose a particularly violent path and his forces were the most ruthless. ZANLA terrorised the population into supporting them through large disciplinary massacres. ${ }^{54}$ Those who were considered sell outs or collaborators of the Rhodesian cause were brutally mutilated and murdered-often entire households were destroyed. Several large-scale massacres were committed of farmworkers to scare them into giving up their jobs at white owned farms. ${ }^{55}$ Nkomo's ZIPRA forces were generally more selective in the violence they inflicted on the population than Mugabe's ZANLA forces. ${ }^{56}$

Despite many similarities, these two leaders chose radically different strategies in the years approaching independence. Kaunda's use of violence was highly constrained, while Mugabe favoured large-scale violence as an overall strategy to achieve his objectives. The choices these leaders made during the liberation struggle were reflective of the strategies with which they would rule their countries in the years that followed. At a structural level, both leaders were faced with similar levels of risk in relation to mass atrocities and at independence the possibility of mass atrocities did not appear inevitable in either country. It is how they responded to such challenges that cemented the path towards or away from mass atrocities.

\section{The Presence of Risk factors at Liberation}

As their countries' inaugural leaders, both Kaunda and Mugabe were faced with a number of challenges associated with the risk of mass atrocities, despite the initial optimism arising from their victorious liberation struggles. One key factor present in both countries was ethno-linguistic division.

Collective tensions based on ethno-linguistic affiliation surfaced in both countries during the struggle for liberation. These affiliations were relatively new-the product of colonial and missionary policies - but they became the basis of coalition-building prior to independence, and following the establishment of multi-party democracies. In Zambia, for example, four ethnolinguistic blocs emerged during colonial rule-Bemba, Tonga, Nyangi and Lozi. ${ }^{57}$ Although the territory comprised as many as seventy-three tribal groups and accompanying languages and dialects, missionary schools chose four languages for instruction and scripture translation. As a result, most Zambians spoke one of these as a first or second language. ${ }^{58}$ While such divisions initially adopted a political dimension during the liberation struggle ${ }^{59}$ it was in the independent state's multi-party framework where they threatened to become institutionally entrenched. ${ }^{60}$

\footnotetext{
${ }^{51}$ Burdette, Zambia, 31; Roberts, Zambia, 220.

${ }^{52}$ Burdette, Zambia, 52.

${ }^{53}$ Wills, History of Central Africa, 351.

${ }^{54}$ Moorcraft, Mugabe's War Machine, 55.

${ }^{55} \mathrm{Ibid}, 55,75,77$.

${ }^{56} \mathrm{Ibid}, 55,77$.

${ }^{57}$ Posner, "Colonial Origins", 129; Roberts, Zambia, 241.

${ }^{58}$ Posner, Daniel N. 2005. Institutions and Ethnic Politics in Africa. Cambridge: Cambridge University Press, 57.

${ }^{59}$ Phiri, Bizeck Jube. 2006. A Political History of Zambia: From the Colonial Period to the $3^{\text {rd } R e p u b l i c . ~ T r e n t o n ~ N J: ~ A f r i c a ~ W o r l d ~}$

Press, 102.

${ }^{60}$ See Molteno, "Cleavage and Conflict".
} 
Zambia's independence heralded almost immediate tensions both within UNIP and between UNIP and other parties, the result of coalition-building along these ethno-linguistic lines. It was during this first decade that recruitment and political competition came to be dominated by ethnolinguistic affiliation. ${ }^{61}$ Alliance-building along these collective lines was seen as a means of securing power and wealth in a country with enormous economic challenges. By 1967, two major blocs had formed in UNIP - Lozi-speakers and Nyanja-speakers on one side, and Bemba and Tonga-speakers on the other. Both blocs were vying for key positions within the government, and threatened to erode the nascent country's unity. ${ }^{62}$ With Kaunda in the middle, both sides accused the other of favouritism. From 1967, these divisions provoked different blocs to form breakaway parties, to the extent that by 1971, all of Zambia's major political parties were characterized by these ethnolinguistic distinctions. ${ }^{63}$ The first decade of Zambia's nationhood was marked by the possibility of ethno-linguistic divisions becoming entrenched and institutionalised.

In Zimbabwe, colonialism also created ethno-linguistic schisms between different groups. While Zimbabweans had always identified themselves politically, as belonging to the community of a particular chief, colonialists differentiated between groups on the basis of their preconceived notions of the origin of the different groups, based on the geography of the country and on perceived differences in language. ${ }^{64}$ The missionaries established ethno-linguistic maps early on primarily distinguishing the Shona and Ndebele as different ethno-linguistic groups, but also differentiating smaller sub-groups. ${ }^{65}$ The group to which a person belonged subsequently determined the access to resources and the job one would occupy, reserving specific jobs for specific groups. ${ }^{66}$ The colonialists believed initially that the Ndebele were superior to the Shona, with similar hierarchical differentiations being made for the subgroups, and this has ultimately created tensions between these groups ${ }^{67}$ The groups therefore were an artificial creation that stemmed from colonial times but have resulted in genuine identification with a particular group. ${ }^{68}$

The nationalist struggle made many value their pre-colonial past in a new light and ethnicity became important to mobilize the masses. ${ }^{69}$ After the ZANU-ZAPU split ZANU came to rely on the predominantly Shona support base and ZAPU on support from the Ndebele. Politicians thus started to use the ethnic schisms as a political tool to increase their own standing and it became a dividing force..$^{70}$ As violence escalated, the war also came to form an additional risk factor which was present in Zimbabwe but not in Zambia. ${ }^{71}$

Further compounding the risk in Zambia, were repeated calls for secession. In Zambia the threat of secession added to the risk for mass atrocities. Secession has also often been associated with the onset of protracted violent wars, ${ }^{72}$ many of which were accompanied by mass atrocities. Previously

\footnotetext{
${ }^{61} \mathrm{Ibid}, 63$.

${ }^{62}$ Roberts, Zambia, 241-245.

${ }^{63}$ Lozi policians in UNIP formed the United Party (UP) in 1966. When the party was banned in August 1968, the Lozi then changed their allegiance to the ANC, which already had a strong Tonga base. In 1971 Bemba leader (and former vice president), Simon Kapwepwe and his Bemba supporters deserted UNIP to form the United Progressive Party (UPP).

${ }^{64}$ Ranger, Terence. 1982. The Invention of Tribalism in Zimbabwe. Gweru: Mambo Press, 14-15.

${ }^{65}$ Ibid, 4-5, 14; Mombeshora, Solomon. 1990. “The Salience of Ethnicity in Political Development: The Case of Zimbabwe." International Sociology Vol. 5, 428.

${ }^{66}$ Ranger, Tribalism in Zimbabwe, 10-14.

${ }^{67} \mathrm{Ibid}, 85$; Chimhundu, Herbert. 1992. "Early missionaries and the ethnolinguistic factor during the "invention of tribalism" in Zimbabwe." Journal of African History Vol. 33, 91-93.

${ }^{68}$ Ranger, Tribalism in Zimbabwe, 19; Chimhundu, "Early Missionaries", 94.

${ }^{69}$ Mombeshora, Solomon. 1990. "The Salience of Ethnicity in Political Development: The Case of Zimbabwe." International Sociology Vol. 5, 432; Muzondidya, James and Sabelo Ndlovu-Gatsheni. 2007. "“'Echoing Silences': Ethnicity in Postcolonial Zimbabwe, 1980-2007." African Journal on Conflict Resolution Vol. 7, No. 2.

${ }^{70}$ Mombeshora, “The Salience of Ethnicity," 433, 437-439; Muzondidya and Ndlovu-Gatsheni, “Echoing Silences," 281-282.

${ }^{71}$ On the risk of atrocities during war, see Shaw, Martin. 2007. "The General Hybridity of War and Genocide." Journal of Genocide Research Vol. 9, No. 3: 461-73; Fein, "Accounting for Genocide"; and Alvarez, Alex. 2001. Governments, Citizens, and Genocide: A Comparative and Interdisciplinary Approach. Bloomington: Indiana University Press. For more on the risk atrocities re-occurring Harff, "No Lessons Learned"; and Midlarsky The Killing Trap, 43-44.

${ }^{72}$ Toft, Monica Duffy. 2012. "Self-Determination, Secession, and Civil War." Terrorism and Political Violence Vol. 24, 592.
} 
known as the Lozi Kingdom (known also as Barotseland), the territory negotiated a separate treaty in 1964, known as the Barotseland Agreement. This guaranteed them some autonomy, in particular through the preservation of their traditional ruling structures. However, these conditions were gradually abrogated, and Kaunda abandoned the Barotseland Agreement in $1969 .{ }^{73}$ Throughout the 1960s and into the 1970s, tensions between Lozi traditional rulers and Lusaka surfaced frequently, with the rulers calling for secession on numerous occasions, although this was counterbalanced by a younger generation of Lozi elected politicians who actively supported the integrity of the Zambian state. ${ }^{74}$

In addition, both countries had to deal with the colonial legacy that had resulted in white privilege and back deprivation and gross economic inequality which posed yet another risk factor. ${ }^{75}$ While the European population in Zambia was smaller by proportion than it was in Zimbabwe, in Zambia the best farmland, and nearly all of its commerce were in the hands of expatriate Europeans. ${ }^{76}$ UNIP had premised self-determination on a redistribution ticket, promising benefits for all. These calls raised expectations among the population that economic wealth would be more equitably shared, through a dramatic increase in service provision, and improved business opportunities for all. In delivering his populist message of redressing these inequities, Kaunda often promised more than he could deliver. Consequently, in the process of raising expectations, some UNIP officials promoted anti-white sentiment, and encouraged suspicion of more moderate political leaders. At independence, there was a growing expectation that the new state would redress these inequalities, and the nationalist movement that UNIP fostered, increased the pressure for immediate, rather than gradual change. ${ }^{77}$

In Zimbabwe too, all the best farmland had been given to the white farmers, but redistribution could only happen under limited circumstances. A compromise was reached on the issue of land redistribution in the Lancaster House Agreement when a peace settlement was agreed upon. It provided that for the first ten years of independence land could only be redistributed on a willing buyer, willing seller basis. ${ }^{78}$ However, despite the existing inequality, upon independence, Zimbabwe's economic prospect nevertheless appeared promising. ${ }^{79}$ Zimbabwe was considered Africa's breadbasket. In comparison to its neighbours it was relatively industrialised, with a rather diverse economy, had better human resources than most of the countries in the region, had a middle income status and foreign governments were quick to offer aid. ${ }^{80}$ Mugabe's initial moves towards reconciliation and his policy of maintaining a capitalist economic system while investing in education and health care, added to this initial optimism that eventually turned out to be mistaken. ${ }^{81}$

Zambia and Zimbabwe shared many of the same risk factors, most notably the enthnolinguistic divisions and horizontal inequality, which were compounded in Zambia by the risk of secession and in Zimbabwe by the legacy of the violent liberation struggle. It seems each could have descended into mass violence at this point. Nevertheless, even though hopes had been particularly high for Zimbabwe's future, the people of Zimbabwe would soon be faced with violence and despair while in Zambia they continued to live in relatively peace.

\footnotetext{
${ }^{73}$ Tordoff, William and Robert Molteno. 1974. "Introduction." In Politics in Zambia. Edited by William Tordoff. Manchester: Manchester University Press, 29; Lindemann, Stefan. 2010. “Inclusive Elite Bargains and Civil War Avoidance: The Case of Zambia." Working Paper No. 77 - Development as State-Making, UK Aid, 12, 15; Sishuwa, S. 2012. "Understanding the Barotseland Question." The Post Online [Zambia], 31 January.

${ }^{74}$ Lindemann, “Inclusive Elite Bargains," 12.

${ }^{75}$ Nafziger and Auvinen, “Economic Development," 156-157.

${ }^{76}$ In the late 1950s, the white population of Northern Rhodesia was 72,000, with a ratio to indigenous Africans approximately 1:30. While the proportion was relatively small, they controlled the best agricultural land, the mines, banks and all other major commercial enterprises (Roberts 1976, 212-214). Similarly in Zimbabwe, at independence, 6,000 white farmers owned $42 \%$ of the land (Palmer 1990, 165).

${ }_{77}$ Phiri, A Political History, 12.

${ }_{78}^{78}$ Palmer, Robin. 1990. “Land Reform in Zimbabwe 1980-1990." African Affairs Vol. 89, 164-166.

${ }^{79}$ Compagnon, Daniel. 2010. A Predictable Tragedy: Robert Mugabe and the Collapse of Zimbabwe. Philadelphia: University of Pennsylvania Press, 192.

${ }^{80}$ Sachikonye, Lloyd M. 2002. "Whither Zimbabwe”, 13; Meredith, Our Votes, Our Guns, 46.

${ }^{81}$ Compagnon, A Predictable Tragedy, 3, 193.
} 


\section{The Role of the Leaders in Mitigating or Aggravating Risk}

The two leaders decided to deal with these risk factors differently. Even though both would speak with a conciliatory tone immediately after being elected, their subsequent tactics diverged dramatically. Kaunda's belief system led him on a balancing act throughout which he continuously tried to unify the nation's different groups, albeit with the added motive of maintaining political dominance. Mugabe continued to use the violent tactics which he had grown accustomed to during the violent war of liberation and rather than accommodating his former enemies, he decided to eliminate them to secure his hold on power.

Kaunda's conciliatory efforts were entrenched in his overarching philosophy of humanism -a combination of socialism, biblical teaching, liberalism and antiracism. First developed in 1967, Humanism was a product of Kaunda's attempt to build a post-colonial Zambian identity. Inspired by his own faith in Christianity, Kaunda regarded humanism as "this high value of man and respect for human dignity," which he believed was inherent in traditional Africa. ${ }^{82}$ Kaunda believed that human dignity could only be maintained in a society that fostered individual freedom and security, through a system of law which was established to protect citizens from people who acted against the common good. ${ }^{83}$ To realize this, Kaunda declared that two things were necessary. First, the government needed to protect its citizens from violations of their dignity and freedom. Second, the individual was duty-bound to demonstrate loyalty to the state. ${ }^{84}$ For this to occur, Kaunda insisted that a government should be free of violence and exploitation.

Kaunda's humanist lens was apparent in the way he responded to growing ethno-linguist divisions during the First Republic. ${ }^{85}$ During the late 1960s and early 1970s, Kaunda stepped up efforts to prevent ethnic competition between political parties and within the ruling UNIP. ${ }^{86}$ He made frequent changes to positions at every tier within the public sector, resulting in rapid turnover of both identity and personnel ${ }^{87}$ Many politicians at the time were increasingly using the language of ethnicity, or tribalism, to attract support and power. In response, Kaunda was careful to divide up important ministerial posts to people from various ethno-linguistic groups in order to maintain a power balance between these main groups. Achieving ethno-linguistic balance within the UNIP government was a near-impossible challenge as alliances between groups shifted and political demands changed..$^{88}$

Kaunda initially adopted a similar approach in response to calls for secession. The signing of the Barotseland Agreement in 1964 was a means of gaining the support of the Lozi Kingdom's traditional rulers. He also empowered a younger cadre of Lozi representatives in the UNIP government by giving them four cabinet positions - as many as the numerically dominant Bemba. ${ }^{89}$ Kaunda was not hesitant in supporting these younger leaders, as a means of undermining the tribal leaders' calls for secession. While this strategy was effective in weakening these calls, it was perceived by other politicians-the Bemba faction in particular-as an act of favouritism. This then provoked tensions between the Lozi politicians and other blocs. In an effort to avoid greater divisions within the government, Kaunda eventually reneged on the Barotseland Agreement. This then provoked an exodus of Lozis from UNIP to the newly formed UP. ${ }^{90}$ Dissatisfied Bemba politicians also left UNIP in 1971, to form the United Progressive

\footnotetext{
${ }^{82}$ Venter, Albert and Michele Olivier. 1993. "Human Rights in Africa: Nyerere and Kaunda." International Journal on World Peace Vol. 10, No. 1, 26-28.

${ }^{83}$ Ibid, 26.

${ }^{84}$ Ibid, 26.

${ }^{85}$ Zambia's political history is typically categorized by three distinct periods - the First Republic, from 1964-1973, characterized by its multi-party democracy; the Second Republic - the period of 'one party' rule from 1973-1991; and the return to multi-party politics in the Third Republic from 1991 to the present.

${ }^{86}$ See, for example, Molteno, "Conflict and Cleavage."

${ }^{87}$ Burdette, Zambia, 30; Kaunda, Zambia, 69; Lindemann, “Inclusive Elite Bargains,” 13.

${ }^{88}$ Burdette, Zambia, 30; Kaunda, Zambia, 71-72.

${ }^{89}$ Tordoff, William and Robert Molteno. 1974. “Government and Administration.” In Politics in Zambia. Edited by William Tordoff. Manchester: Manchester University Press, 246-247.

${ }^{90}$ Molteno, “Cleavage and Conflict," 91.
} 
Party (UPP). Clearly, managing calls for secession provoked other problems, which also needed to be solved. ${ }^{91}$

But despite the magnitude of these challenges, Kaunda stopped short of using violence to cope with the different groups. This stands in stark contrast with Mugabe, who believed violence was an integral part of politics. During the Rhodesian war he summed up his perspective on electoral democracy:

Our votes must go together with our guns. After all, any vote we shall have, shall have been the product of the gun. The gun which produces the vote should remain its security officerits guarantor. The people's votes and the people's guns are always inseparable twins. ${ }^{92}$

This was brought to fruition in the elections that were to follow. All parties used intimidation during the countries' first election campaign after independence, but none to the extent that ZANU did. Killings were combined with threats that the war would be continued if ZANU would not win. ${ }^{93}$

Soon after winning the elections, Mugabe briefly changed into "a model of moderation." 94 Mugabe in a public speech assured the country that "there is no intention on our part to use out majority to victimise the minority. We will ensure that there is a place for everyone in this country. ... Let us deepen our sense of belonging and engender a common interest that knows no race, colour or creed." ${ }^{95}$ In addition, he willingly offered his former competitor Nkomo a seat in his government. The conciliatory tone, however, would soon change. ${ }^{96}$ After a series of violent events orchestrated by units under South African control, Mugabe indicated the honeymoon was over. He accused the white population of colluding with South Africa, of not showing remorse and started to berate the white community as a whole. ${ }^{97}$ Joshua Nkomo and his ZAPU party did not fare any better. The first signs that the tensions between the parties would again turn violent emerged soon after independence at Entumbane in November 1980 and again in February 1981. The first violent episode erupted after a close associate of Mugabe held an inflammatory speech in Bulawayo were former ZIPRA and ZANLA guerrillas were housed. ${ }^{98}$ When fighting broke out again, Mugabe deployed the former Rhodesian army against former ZIPRA soldiers to quell the violence. ${ }^{99} \mathrm{ZAPU}$, ZIPRA and their predominantly Ndebele supporters were increasingly portrayed as villains and by 1983, all of the military or political leadership of ZAPU had been arrested or forced into exile and violence and disappearances of former ZIPRA military personnel was common. ${ }^{100}$

The situation would soon deteriorate as Mugabe's forces killed approximately 20,000 people in Matabeleland. Although the overriding objective was probably the destruction of Nkomo's

\footnotetext{
${ }^{91}$ Indeed in the chaos of growing divisions within UNIP, many parliamentarians left to form new parties, mostly characterised by ethnicity, further threatening the political stability of the new country. Kaunda's response was to place bans on such parties, and finally establishing a one party state in 1972, with UNIP the only permitted party within parliament. This saw a growing concentration of power within the executive office, and provoked other challenges to political stability. For more on both internal and external pressure for Kaunda to lift the ban on political parties in 1991, see Bratton, Michael. 1992. "Zambia Starts Over." Journal of Democracy Vol. 3, No. 4; Larmer, Miles. 2009. "Zambia Since 1990: Paradoxes of Democratic Transition." In Turning Points in African Democracy. Edited by Abdul Raufu Mustapha and Lindsay Whitfield. Cumbria: James Currey; and McLoughlin, Stephen. 2014. The Structural Prevention of Mass Atrocities: Understanding Risk and Resilience. Oxon: Routledge.

${ }^{92}$ Meredith, Our Votes, Our Guns, 225.

${ }^{93}$ Meredith, Our Votes, Our Guns, 10; Kriger, Norma J. 2004. Guerilla Veterans in Post-War Zimbabwe: Symbolic and Violent Politics, 1980-1987. Cambridge, Cambridge University Press, 4-5.

${ }^{94} \mathrm{Ibid}, 13$.

${ }^{95} \mathrm{Ibid}, 13$.

${ }^{96} \mathrm{Ibid}, 13,19$.

${ }^{97}$ Ibid, 52.

${ }^{98} \mathrm{Ibid}, 61$.

${ }^{99} \mathrm{Ibid}, 62$.

${ }^{100}$ Jackson, Paul. 2011. “The Civil War Roots of Military Domination in Zimbabwe: The Integration Process Following the Rhodesian War and the Road to ZANLA Dominance." Civil Wars Vol. 13, No. 4, 385; Catholic Commission for Justice, "Breaking the Silence"; Muzondidya and Ndlovu-Gatsheni, "Echoing Silences," 285.
} 
support base, given the extent to which political support and ethnicity were intertwined, the effect was that the Ndebele were almost exclusively targeted. ${ }^{101}$ The pretext for the violence were arms caches which had been found and the threat posed by violent dissident activity but this was highly exaggerated by the government. ${ }^{102}$ The dissidents were largely leaderless, and there is no evidence that they were supported by ZAPU. ${ }^{103}$ Mugabe sought the help of North Korea to train the fifth brigade of the national army, composed entirely of his Shona speaking followers, and send them into Matabeleland where they unleased a reign of terror. ${ }^{104}$ The Brigade was to be called Gukurahundi-which translates as "the rain which washes away the chaff before the spring rains." 105

The violence ended with the Unity Accords in 1987, merging ZAPU and ZANU into ZANUPF. For ZAPU it was essentially "a surrender document." 106 The violence has had long term effect of deepening the ethnic-linguistic divisions in the country. National integration has become more difficult as the violence enhanced feelings of Ndebele distinctiveness, was a source of resentment and caused many to view the Shona more generally as responsible. ${ }^{107}$

Through these policies Mugabe aggravated and enhanced the already existing ethno linguistic cleavages while killing thousands in the first few years in power. ${ }^{108}$ Kaunda on the other hand was guided by his inclusive ideas and accommodated political policies to minimise tensions between the groups. In their economic policies, however, both Kaunda and Mugabe acted uncompromisingly harsh towards any political opponents. Both initially improved the economic situation of their countries, focussing on social services but eventually keeping their conies happy, and maintaining their position of power, was prioritised over the welfare of their respective populations.

In the beginning the economic policies of the countries seemed to be commendable and the future looked bright. Kaunda's efforts to redress the country's profound economic inequalities resulted in improved wealth and service provision. Between 1964 and 1970, annual earnings of indigenous Zambians rose by 97 percent. The manufacturing sector doubled its output, and the number of people employed rose by nearly 40 percent. ${ }^{109}$ In Zimbabwe, similarly, the economy experienced a major boom in the first two years of independence, growing 24 percent in just two years, which benefitted both the black and white population. ${ }^{110}$ Mugabe invested in education and the social sectors especially in the rural areas but despite these improvements, the new economic successes predominantly seemed to benefit the new black elite. ${ }^{111}$ According to Compagnon, "those who were not part of the patronage system found it difficult to survive in post-Independence Zimbabwe."112

The economic policies of both of these leaders were tied to maintaining their positions of power and neutralising any opposition. In Zambia trade licences were no longer issued for nonmembers of UNIP, loan applications in ANC strongholds were revoked, and even water taps were disconnected. ${ }^{113}$ Kaunda's intolerance of his political opponents and their supporters translated

\footnotetext{
${ }^{101}$ Phimister, Ian. 2008. “The Making and Meanings of the Massacres in Matabeleland." Development Dialogue No. 50, 198, 209-210.

${ }^{102}$ Phimister, "Massacres in Matabeleland," 198; Muzondidya and Ndlovu-Gatsheni, "Echoing Silences", 285; Catholic Commission for Justice.

${ }^{103}$ Catholic Commission for Justice.

${ }^{104}$ Catholic Commission for Justice; Phimister, “Massacres in Matabeleland", 198.

${ }^{105}$ Catholic Commission for Justice.

${ }^{106}$ Ndlovu-Gatsheni, Sabelo J. 2008. “Nation Building in Zimbabwe and the Challenges of Ndebele Particularism." African Journal on Conflict Resolution Vol. 8, No. 3, 48.

${ }^{107}$ Muzondidya and Ndovlu-Gatsheni, “Echoing Silences", 286.

${ }^{108}$ Ibid, 286; Phimster, "Massacres in Matabeleland", 210.

${ }^{109}$ Tordoff and Molteno, “Government and Administration", 363.

${ }^{110}$ Meredith, Our Votes, Our Guns, 45-46; Compagnon, A Predictable Tragedy, 193-194.

${ }^{111}$ Sachikonye, "Whither Zimbabwe", 13; Compagnon, A Predictable Tragedy, 193-194; Addison, Tony and Liisa Laakso. 2003. “The Political Economy of Zimbabwe's Descent into Conflict." Journal of International Development Vol 15, 458.

${ }^{112}$ Compagnon, A Predictable Tragedy, 194.

${ }^{113}$ Phiri, A Political History, 142-143.
} 
into economic discrimination. By the early 1970s, it was becoming clear that supporting UNIP had benefits, and supporting the opposition had palpable disadvantages. While Kaunda did not resort to acts of violence against opposition supporters, openly opposing UNIP had clear economic consequences, and such discriminatory practices inevitably targeted specific ethno-linguistic groups, according to their allegiances. ${ }^{114}$

In Zimbabwe too perks were handed out to those willing to conform to the party line. The new and large public sector became an important tool for Mugabe's patronage as it allowed him to assign many desirable positions to his cronies and their family. ${ }^{115}$ While in the 1980s corruption was almost nothing in comparison to the scale it would become, the seeds had been sown. ${ }^{116}$

These formative years showed glimpses of what was to come in the years thereafter. Zimbabwe would continue to be bogged down in economic malaise and episodes of brutal political violence while Zambia eventually was to remain relatively stable. ${ }^{117}$ Kaunda eventually resigned under extreme pressure that resulted from both popular opposition and from within the ranks of his own party, as a consequence of his mismanagement. ${ }^{118}$

\section{Other Factors that May Explain the Difference in the Level of Violence}

In this section, we consider other factors that may have impacted on the two countries' different paths. We find that typically prohibitive factors in relation to mass atrocities, such as democratic constraint on power and a strong independent judiciary, ${ }_{119}^{119}$ were weak in both countries. The clear point of distinction is each country's decolonization process. For Zambia, it was largely nonviolent, whereas in Zimbabwe, it was achieved only after a protracted civil war. However, neither Zimbabwe's civil war, nor Zambia's peaceful independence struggle made atrocities inevitable in one country nor impossible in the other. With all these factors taken into account, what we see is one leader (Kaunda) acting as lone voice against growing ethno-linguistic division, and one leader (Mugabe) proactively aggravating ethnic division through his violent policies, which culminated in the Gukurahundi, as a way of cementing his power and neutralizing rivals. ${ }^{120}$

At independence, both countries started with tangible constraints on the power of the executive. Both states initiated multi-party electoral systems, which spawned parliaments with a diverse range of voices. While both victorious parties received strong majorities, opposition parties were also strongly represented. However, these constraints were slowly eroded in both countries. In Zambia, Kaunda began prohibiting opposition parties in the late 1960s, and by 1973 he introduced a blanket ban on all opposition parties, effectively heralding a long period of one party rule. ${ }^{121}$ In Zimbabwe, Mugabe also brought about a de facto one party state. Yet while opposition parties were subject to violent intimidation, he did not prohibit them, as Zambia had. Both leaders also increased their own power, lessening constraints on the executive. In Zimbabwe Mugabe allowed little flexibility for opposition voices; he did not tolerate dissent and it was virtually impossible to express any opposition to Mugabe within the party. ${ }^{122}$ In Zambia, Kaunda eroded the power of the cabinet, and transferred key portfolios to the office of the president. ${ }^{123}$ In terms of institutional constraints in relation to the risk of mass atrocities, both countries displayed similar patterns - both started with democratic systems; both marginalized opposition voices; and both substantially increased their own power. If anything, Zambia became less democratic than Zimbabwe through its outright ban on political parties. Thus, regime type alone

\footnotetext{
${ }^{114}$ Ibid, 143.

${ }^{115}$ Compagnon, A Predictable Tragedy, 193-194.

${ }^{116}$ Chan, Robert Mugabe, 43.

${ }_{117}$ Compagnon, A Predictable Tragedy, 193-194.

${ }^{118}$ Phiri, A Political History, 166-169.

${ }^{119}$ See, for example, Goldstone, Jack A. and Jay Ulfelder. 2004. "How to Construct Stable Democracies." The Washington Quarterly Vol. 28, No. 1; Krain, "Democracy, Internal War"; McLoughlin, The Structural Prevention of Mass Atrocities.

${ }^{120}$ Muzondidya and Ndlovu-Gatsgeni, “Echoing Silences", 286; Phimster, "Massacres in Matabeleland, 210.

${ }^{121}$ Roberts, Zambia, 247-249.

${ }^{122}$ Compagnon, A Predictable Tragedy, 15

${ }^{123}$ Phiri, A Political History, 162-165.
} 
does not explain why Zambia effectively managed risk, while atrocities were committed in Zimbabwe.

While an independent judiciary can act as a safety net in the face of discriminatory government policies, ${ }^{124}$ in both countries the judiciary was steadily marginalised, or manipulated during the first decade of independence. In Zambia, Kaunda gradually replaced all High Court judges who made decisions against the government, until the judiciary was stacked with judges known to favour the government. While he did not contradict or ignore rulings in the High Court-including those that challenged government policy-his appointment of regime-friendly judges resulted in a weakened judiciary. ${ }^{125}$ In Zimbabwe, there appeared to be more constraint - the judiciary maintained its independence during the country's formative years, and there is no indication that Mugabe went as far as Kaunda by appointing regime-friendly judges. As Compagnon puts it, "There is near consensus that in the early years Mugabe endorsed the JSC [Judicial Service Commission, an independent commission headed by the chief justice] recommendations and did not seek to impose partisan judges, although nothing in the constitution barred him from doing so." ${ }^{126}$ Hatchard, likewise points out that in the 1980 s "the executive ... respected the independence of the judiciary". ${ }^{127}$

However, when it came to the atrocities in Matabeleland, the judiciary did not constrain Mugabe's actions. From independence until 1990, Mugabe utilized emergency powers to act with impunity in Matabeleland. By declaring a state of emergency, this triggered the operation of the Emergency Powers Act, which enabled Mugabe to "make regulations for, inter alia, the public safety and maintenance of public order."128 This act-originally introduced by the Smith government in 1965-was the legal mechanism Mugabe utilized to deal with a number of issues in the country for the entire first decade of independence, including the troubles in Matabeleland. While the provision of emergency powers was not intended for such a long period of time-indeed, the Act dictated a maximum of six-month stretches-Mugabe's extended use of emergency powers for a such lengths is most likely indicative of an intention to "circumvent the constitutional process and to rule by decree." ${ }^{129}$ In Zimbabwe, Mugabe manipulated the constitution through his use of emergency powers, circumventing the judiciary, and casting a thin veil of legal legitimacy over his increased powers. As an institution with the potential to constrain the actions of government, the role of the judiciary in both countries does not provide any clarity to the different paths each country took. It did not facilitate risk mitigation in Zambia, nor did it have an inhibitory effect on the perpetration of atrocities in Zimbabwe.

The strongest point of difference between the two countries is the character of the decolonization process. In Zambia, it was ostensibly peaceful-it allowed for growing African representation within the colonial Legislative Council, which then precipitated a vote for independence. This is not to diminish the enormity of challenges the country faced at independence. Kaunda presided over a country that was profoundly poor, with very limited resources. The main source of wealthcopper and other minerals - were in the hands of European expatriates, as was the best farmland. However, the road to independence was marked by effective strategies of civil disobedience that led to an accumulation of social and political victories in the lead-up to independence, heralding a relatively non-violent beginning to independence.

Zimbabwe's road to independence was in stark contrast to this-after Ian Smith's UDI in 1965, the prospects of a similar path to liberation were destroyed. Even Kaunda believed that independence in Rhodesia could only come about through a military intervention of sorts, and publicly declared his support for such action. Kaunda appealed for the British to stage a swift military intervention to overthrow the Smith regime and allow for universal enfranchisement-

\footnotetext{
${ }^{124}$ McLoughlin, The Structural Prevention, 66-67.

${ }^{125}$ Burdette, Zambia, 332.

${ }^{126}$ Compagnon, A Predictable Tragedy, 143.

${ }^{127}$ Hatchard, John. 1991. "The Constitution of Zimbabwe: Towards a Model for Africa." Journal of African Law Vol. 35, No. 1-2, 92 .

${ }^{128}$ Ibid, 89.

${ }^{129} \mathrm{Ibid}, 89$.
} 
this, he believed, was the only way to avoid a protracted and violent struggle for independence. ${ }^{130}$ This is what indeed happened, thus Zimbabwe's independence commenced on the back of a long and bloody conflict, which saw fighting break out not only between guerrilla forces and the Smith regime, but also between different guerrilla forces. It was this latter dynamic that spilled over into the early years of independent statehood.

Yet, not even this dynamic is sufficient to explain the perpetration of mass atrocities in Matabeleland. Unresolved tensions escalated into violence on several occasions in the first couple of years of independence. Most of this violence arose from skirmishes between the two militias that were active in the civil war-Nkomo's ZIPRA, and Mugabe's ZANLA. ${ }^{131}$ While the country was in the process of integrating these militia into the national army, problems frequently surfaced, and both camps had to deal with renegade (former) guerrillas. Elements in both militias did not immediately transfer allegiance to the new state. ZIPRA militants in particular had difficulty with integration into the army. They were the smaller force, and largely spoke Sindebele, while the majority of soldiers in the army spoke Shona. ${ }^{132}$ There were several violent encounters between the groups, most notoriously at Entumbane. ${ }^{133}$ Although there were possibly hundreds of casualties arising from these skirmishes, ${ }^{134}$ these events did not by themselves lead to widespread atrocities being perpetrated.

The transformation of this violence into the perpetration of atrocities in Matabeleland was the direct result of Mugabe's extreme response to the instability. He set up a new a new military contingent, the Fifth Brigade, and recruited North Korean military advisers to provide training. ${ }^{135}$ He further demonized and isolated Nkomo, accusing him of cooperating with South Africa, which was destabilizing the region, and finally dispatched the Fifth Brigade to Matabeleland, to target not only ZIPRA militants, but also unarmed civilians, killing 20,000 people. ${ }^{136}$ While rogue ZIPRA and ZANLA elements did indeed provoke sporadic clashes, the mass atrocities in Matabeleland did not inevitably arise from these clashes. They were the direct product of Mugabe's Fifth Brigade, under orders to target not only the small contingents of militants, but the broader public, who were mostly unarmed civilians.

Institutional constraints that typically have an inhibitory effect on mass atrocities were, if anything, stronger in Zimbabwe than they were in Zambia. Despite this, the first decade of independence witnessed an eroding of democratic and judicial accountability in both countries. As such, these characteristics provide little explanation as to why risk was managed in Zambia, and why atrocities were perpetrated in Zimbabwe. In Zambia, the only force that resisted the tendency towards the entrenchment of ethno-linguistic differences in Zambia's nascent parliament was Kaunda himself. In Zimbabwe, Mugabe sidestepped judicial accountability by enacting emergency powers that Ian Smith had initiated. While ongoing tensions between ZIPRA and ZANLA provoked sporadic violent clashes, they do not provide an explanation for the dramatic and extreme targeting of unarmed civilians in Matabeleland. It was only after Mugabe established, trained and despatched the Fifth Brigade to the region that atrocities were perpetrated, and the clashes between militants spilled over into the civilian population.

\section{Conclusion}

Despite the dramatically different paths Zambia and Zimbabwe have taken since independence, the two countries share striking similarities in terms of their historical backgrounds, and structural risk factors in relation to mass atrocities. The different paths these two countries took can be strongly attributed to the strategies and behaviour of their inaugural presidents - Kenneth Kaunda

\footnotetext{
${ }^{130}$ Kaunda, Zambia, 162.

${ }^{131}$ Meredith, Martin. 2007. Power, Plunder and the Struggle for Zimbabwe's Future. New York: Perseus, 59-60.

${ }^{132} \mathrm{Ibid}, 60$.

${ }^{133} \mathrm{Ibid}, 60-61$.

${ }^{134} \mathrm{Ibid}, 62$.

${ }^{135} \mathrm{Ibid}, 62$.

${ }^{136}$ Compagnon, A Predictable Tragedy, 25-26; Meredith, Power, Plunder, 60-73; Phimster, "Massacres in Matabeleland”, 198.
} 
and Robert Mugabe. More specifically, the role that both leaders played in steering their countries along different trajectories can be understood through an examination of how they responded to structural risk factors contingent in each country during the early years of independence.

The historical background of these countries had much in common. Both were former British protectorates, which had encouraged European migration and entrepreneurship, while systematically discriminating against their indigenous African populations. This resulted in the expatriate white population controlling the lion's share of wealth and fertile agricultural land in both territories. The concentration of white economic and political power intensified after the two territories (along with Nyasaland) joined to form the Central African Republic in 1953. This entity also amplified calls for majority-rule by each territory's growing liberation movements. Eventually their paths towards independence differed significantly but Zambia's peaceful beginning and Zimbabwe's violent independence struggle did not mean that the outcome of peace in the former and violence in the latter were inevitable.

The key distinguishing factor which explains the divergent paths of Zambia and Zimbabwe can be found in their inaugural leaders-Kaunda and Mugabe. An early indication of their difference in strategy was the contrasting ways that each leader managed the impact that colonial constructions of ethnicity had on the risk of mass atrocities. In Zambia, Kaunda's guiding philosophy of humanism saw him engaged in a complex and time-consuming process of managing rivalries based on ethno-linguistic allegiances. By frequently reshuffling ministerial posts and top-level public sector positions, he effectively mitigated against the possibility that such identity-based differences would become institutionally entrenched. Kaunda's inclusive ideology informed his inclusive approach to nation-building, an approach which attempted to transcend such differences. As Kaunda himself said, "with any luck, this generation will think of itself not in tribal terms as Bemba, Lozi or Tonga, but as Zambians. This is the only guarantee of future stability." ${ }^{137}$ Despite the growing identity-based divisions in the 1960s, this occurred largely at the elite level-in Zambia's particular context, such divisions had not permeated more broadly. This meant that Kaunda's strategies to temper such divisions at the elite level were sufficient to contain the problem. Mugabe's seasoned wartime strategy of targeting not only the Rhodesian state but also his main rival faction, ZIPRA, the military wing of Nkomo's ZAPU carried over into independence. The attempts by South Africa to destabilize the country, and the clashes with former ZIPRA guerrillas, can be seen as triggers for Mugabe's violent response. However, even though explanations that focus on the 1980-1982 period are important, they do not help to explain the Fifth Brigade's brutal tactics which they relied on from the very start of the Gukurahundi. ${ }^{138}$ In order to understand the intensity of the violence during this period, it is necessary to take Mugabe's political strategy into account. With political competition in Zimbabwe's nascent democracy materializing along ethnolinguistic lines, Mugabe's strategy to cement ZANU's victory and his own political dominance was to erode Nkomo's Ndebele support base by massacring 20,000 of them in Matabeleland in 1983, three years after independence. ${ }^{139}$

This analysis has focused on the ways that these two leaders interacted with the structural risk factors associated with mass atrocities, most of which were products of each country's colonial history. The comparable level of risk in Zambia and Zimbabwe suggests that the presence of structural risk does not necessitate a particular outcome. In these two cases, the behaviour and strategies of the two inaugural leaders prompted patterns of violence or constraint that had a decisive influence on the perpetration of atrocities, or the effective mitigation of risk over time.

\section{Bibliography}

Addison, Tony and Liisa Laakso. 2003. “The Political Economy of Zimbabwe's Descent into Conflict." Journal of International Development Vol 15, No. 4: pages 457-70. http://dx.doi. org/10.1002/jid.996

\footnotetext{
${ }^{137}$ Kaunda, Zambia, 91.

${ }^{138}$ Phimster, "Massacres in Matabeleland", 205.

${ }^{139}$ Ibid, 198, 210.
} 
Alvarez, Alex. 2001. Governments, Citizens, and Genocide: A Comparative and Interdisciplinary Approach. Bloomington: Indiana University Press.

Ban Ki-moon. 2009 "Implementing the Responsibility to Protect." A/63/677. New York: United Nations.

Bratton, Michael. 1992. "Zambia Starts Over." Journal of Democracy Vol. 3, No. 4: pages 81-94. http://dx.doi.org/10.1353/jod.1992.0027

Burdette, Marcia M. 1988. Zambia: Between Two Worlds. Boulder: Westview Press.

Byman, Daniel L. and Kenneth M. Pollack. 2001. "Let Us Now Praise Great Men: Bringing the Statesman Back In" International Security Vol. 25, No. 4: pages107-146. http://dx.doi. org $/ 10.1162 / 01622880151091916$

Byman, Daniel. 2002. Keeping the Peace: Lasting Solutions to Ethnic Conflicts. Baltimore: John Hopkins University Press.

Catholic Commission for Justice and Peace \& Legal Resources Foundation (CCJPZ \& LRF). 1999. "Breaking the Silence, Building True Peace: A Report on the Disturbances in Matabeleland and the Midlands 1980-1988". Available from http://www.hrforumzim.org/publications/ reports-on-political-violence/reaking-the-silence/ (accessed November 2014).

Chan, Stephen. 2003. Robert Mugabe: a Life of Power and Violence. London: I.B. Taurus.

Chandler, David P. 1999. Brother Number One: A Political Biography of Pol Pot. Bangkok: Silkworm Books.

Chimhundu, Herbert. 1992. "Early Missionaries and the Ethnolinguistic Factor During the "Invention of Tribalism" in Zimbabwe." Journal of African History Vol. 33, No. 1: pages 87-109. http://dx.doi.org/10.1017/S0021853700031868

Chirot, Daniel. 1994. Modern Tyrants: The Power and Prevalence of Evil in Our Age. New York: The Free Press.

Compagnon, Daniel. 2010. A Predictable Tragedy: Robert Mugabe and the Collapse of Zimbabwe. Philadelphia: University of Pennsylvania Press.

Ezrow, Natasha and Erica Frantz. 2011. Dictators and Dictatorships: Understanding Authoritarian Regimes and their Leaders. New York: Continuum.

Helen Fein. 1993. "Accounting for Genocide after 1945: Theories and Some Findings." International Journal on Group Rights Vol. 1, No. 2: pages 79-106. http://dx.doi.org/10.1163/ $\underline{157181193 \times 00013}$

Fein, Helen. 1995. "More Murder in the Middle: Life-Integrity Violations and Democracy in the World, 1987." Human Rights Quarterly Vol. 17, No. 1:pages 170-91.http://dx.doi.org/10.1353/ hrq.1995.0001

Goldhagen, Daniel Jonah. 2009. Worse Than War: Genocide, Eliminationism, and the Ongoing Assault on Humanity. New York: Public Affairs.

Goldstone, Jack A. and Jay Ulfelder. 2004. "How to Construct Stable Democracies." The Washington Quarterly Vol. 28, No. 1: pages 9-20. http://dx.doi.org/10.1162/0163660042518198

Good, Robert C. 1973. U.D.I.: The International Politics of the Rhodesian Rebellion. Princeton: Princeton University Press.

Hamburg, David. 2008. Preventing Genocide: Practical Steps toward Early Detection and Effective Action. Boulder: Paradigm Publishers.

Harff, Barbara. 2003. "No Lessons Learned from the Holocaust? Assessing Risks of Genocide and Political Mass Murder since 1955." American Political Science Review Vol. 12, No. 1: pages 57-73. http://dx.doi.org/10.1017/S0003055403000522

Hatchard, John. 1991. "The Constitution of Zimbabwe: Towards a Model for Africa." Journal of African Law Vol. 35, No. 1-2: pages 79-101. http://dx.doi.org/10.1017/S0021855300008378

Holland, Heidi. 2008. Dinner with Mugabe: The Untold Story of a Freedom Fighter who Became a Tyrant. London: Penguin Books.

Jackson, Robert H. and Carl G. Rosberg. 1982. Personal Rule in Black Africa: Prince, Autocrat, Prophet, Tyrant. Berkeley, University of California Press.

Jackson, Paul. 2011. "The Civil War Roots of Military Domination in Zimbabwe: The Integration Process Following the Rhodesian War and the Road to ZANLA Dominance." Civil Wars Vol. 13, No. 4: pages 371-95. http://dx.doi.org/10.1080/13698249.2011.629865 
Kaunda, Kenneth. 1962. Zambia Shall be Free. London: Heinemann.

Kaunda, Kenneth. 1980. The Riddle of Violence. New York: Harper and Row.

Kershaw, Ian. 1998. Hitler: A Biography. New York: W.W. Norton \& Company Inc.

Krain, Matthew. 2000. "Democracy, Internal War, and State-Sponsored Mass-Murder." Human Rights Review Vol. 1, No. 3: pages 40-48. http://dx.doi.org/10.1007/s12142-000-1020-0

Kriger, Norma J. 2004. Guerilla Veterans in Post-War Zimbabwe: Symbolic and Violent Politics, 19801987. Cambridge: Cambridge University Press.

Kuper, Leo. 1981. Genocide: Its Political Use in the Twentieth Century. Middlesex: Penguin Books.

Langer, Arnim. 2008. “When do Horizontal Inequalities Lead to Conflict?" In Horizontal Inequalities and Conflict: Understanding Group Violence in Multiethnic Societies. Edited by Frances Stewart. New York: Palgrave Macmillan.

Larmer, Miles. 2009. "Zambia Since 1990: Paradoxes of Democratic Transition." In Turning Points in African Democracy. Edited by Abdul Raufu Mustapha and Lindsay Whitfield. Woodbridge, Suffolk: James Currey.

Lindemann, Stefan. 2010. "Inclusive Elite Bargains and Civil war Avoidance: The Case of Zambia." Working Paper No. 77 - Development as State-Making, UK Aid.

Mahoney, James and Gary Goertz. 2004. "The Possibility Principle: Choosing Negative Cases in Comparative Research." American Political Science Review Vol. 98, No. 4: pages 653-69. http://dx.doi.org/10.1017/S0003055404041401

Maxey, Kees. 1975. The Fight for Zimbabwe: The Armed Conflict in Southern Rhodesia since UDI. London: Rex Collings.

Mayersen, Deborah and Stephen McLoughlin. 2011. "Risk and Resilience to Mass Atrocities in Africa: A Comparison of Rwanda and Botswana." Journal of Genocide Research Vol. 12, No. 3: pages 247-69. http://dx.doi.org/10.1080/14623528.2011.606687

McLoughlin, Stephen. 2014. The Structural Prevention of Mass Atrocities: Understanding Risk and Resilience. Oxon: Routledge.

Meredith, Martin. 2002. Our Votes, Our Guns: Robert Mugabe and the tragedy of Zimbabwe. New York: Public Affairs.

Meredith, Martin. 2007. Power, Plunder and the Struggle for Zimbabwe's Future. New York: Perseus.

de Mesquita, Bruce Bueno and Alastair Smith. 2011. The Dictator's Handbook: Why Bad Behaviour is Almost Always Good Politics. New York: Public Affairs.

Midlarsky, Manus I. 2005. The Killing Trap: Genocide in the Twentieth Century. Cambridge: Cambridge University Press. http://dx.doi.org/10.1017/CBO9780511491023

Moghaddam, Fathali M. 2013. The Psychology of Dictatorship. Washington, DC: American Psychological Association. http://dx.doi.org/10.1037/14138-000

Moorcraft, Paul. 2011. Mugabe's War Machine: Saving or Savaging Zimbabwe? Barnsley: Pen \& Sword Military.

Molteno, Robert. 1974. "Cleavage and Conflict in Zambian Politics: A Study in Sectionalism." In Politics in Zambia. Edited by William Tordoff. Manchester: Manchester University Press.

Mombeshora, Solomon. 1990. "The Salience of Ethnicity in Political Development: The Case of Zimbabwe." International Sociology Vol. 5, No. 4: pages 427-44. http://dx.doi. org/10.1177/026858090005004005

Muzondidya, James and Sabelo Ndlovu-Gatsheni. 2007. “'Echoing Silences': Ethnicity in Post-colonial Zimbabwe, 1980-2007." African Journal on Conflict Resolution Vol. 7, No. 2: pages 275-297.

Nafziger, E. Wayne and Juha Auvinen. 2002. "Economic Development, Inequality, War and State Violence." World Development Vol. 30, No. 2: pages 153-163. http://dx.doi.org/10.1016/ S0305-750X(01)00108-5

Ndlovu-Gatsheni, Sabelo J. 2008. "Nation Building in Zimbabwe and the Challenges of Ndebele Particularism." African Journal on Conflict Resolution Vol. 8, No. 3: pages 27-56.

Padilla, Art, Robert Hogan and Robert B. Kaiser. 2007. "The Toxic Triangle: Destructive Leaders, Susceptible Followers and Conducive Environments." The Leadership Quarterly Vol. 18, No. 3: pages 176-94. http://dx.doi.org/10.1016/j.leaqua.2007.03.001

Palmer, Robin. 1990. “Land Reform in Zimbabwe 1980-1990." African Affairs Vol. 89, No. 355: pages 163-81. 
Phimister, Ian. 2008. "The Making and Meanings of the Massacres in Matabeleland." Development Dialogue No. 50, December: pages 197-214.

Phimster, Ian. 2009. "'Zimbabwe is Mine': Mugabe, Murder, and Matabeleland." Safundi: The Journal of South African and American Studies Vol. 10, No. 4: pages 471-78. http://dx.doi. org/10.1080/17533170903210996

Phiri, Bizeck Jube. 2006. A Political History of Zambia: From the Colonial Period to the $3^{\text {rd }}$ Republic. Trenton NJ: Africa World Press.

Posner, Daniel N. 2003. "The Colonial Origins of Ethnic Cleavages: The Case of Linguistic Divisions in Zambia." Comparative Politics Vol. 35, No. 2: pages 127-146. http://dx.doi. org/10.2307/4150148

Posner, Daniel N. 2005. Institutions and Ethnic Politics in Africa. Cambridge: Cambridge University Press. http://dx.doi.org/10.1017/CBO9780511808661

Post, Jerrold M. 2004. Leaders and Their Followers in a Dangerous World: The Psychology of Political Behavior. Ithaca: Cornell University Press.

Ranger, Terence. 1982. The Invention of Tribalism in Zimbabwe. Gweru: Mambo Press.

Regan, Patrick M. and Errol A. Henderson. 2002. "Democracy, Threats and Political Repression in Developing Countries: Are Democracies Internally Less Violent?" Third World Quarterly Vol. 23, No.1: pages 119-36. http://dx.doi.org/10.1080/01436590220108207

Roberts, Andrew. 1976. A History of Zambia. London: Heinemann.

Rummel, Rudolph J. 1994. "Power, Genocide and Mass Murder." Journal of Peace Research Vol. 31, No. 1: pages 1-10. http://dx.doi.org/10.1177/0022343394031001001

Sachikonye, Lloyd M. 2002. "Whither Zimbabwe? Crisis and Democratisation." Review of African Political Economy Vol. 29, No. 91: pages 13-20. http://dx.doi. org/10.1080/03056240208704581

Shaw, Martin. 2007. "The General Hybridity of War and Genocide." Journal of Genocide Research Vol. 9, No. 3: pages 461-73. http://dx.doi.org/10.1080/14623520701584281

Sishuwa, S. 2012. "Understanding the Barotseland Question." The Post Newspaper. Available from www.postzambia.com/Joomla/postread article.php?articleId=24887 (accessed 31 January 2015).

Stanton, Gregory. 2004. "Could the Rwandan Genocide have been Prevented?" Journal of Genocide Research Vol. 6, No. 2: pages 211-28. http://dx.doi.org/10.1080/1462352042000225958

Stewart, Frances. 2008. "Horizontal Inequalities and Conflict: An Introduction and Some Hypotheses." In Horizontal Inequalities and Conflict: Understanding Group Violence in Multiethnic Societies. Edited by Frances Stewart. New York: Palgrave Macmillan. http://dx.doi. org/10.1057/9780230582729

Staub, Ervin 2010. Overcoming Evil: Genocide, Violent Conflict and Terrorism. Oxford: Oxford University Press. http://dx.doi.org/10.1093/acprof:oso/9780195382044.001.0001

Straus, Scott 2012. "Retreating from the Brink: Theorizing Mass Violence and the Dynamics of Restraint." Perspectives on Politics Vol. 10, No. 2: pages 343-62. http://dx.doi.org/10.1017/ $\underline{\mathrm{S} 1537592712000709}$

Toft, Monica Duffy. 2012. "Self-Determination, Secession, and Civil War." Terrorism and Political Violence Vol. 24, No. 4: pages 581-600. http://dx.doi.org/10.1080/09546553.2012.700617

Tordoff, William and Robert Molteno. 1974. "Introduction." In Politics in Zambia. Edited by William Tordoff. Manchester: Manchester University Press.

Tordoff, William and Robert Molteno. 1974. "Government and Administration." In Politics in Zambia. Edited by William Tordoff. Manchester: Manchester University Press.

Valentino, Benjamin. 2004. Final Solutions: Mass Killing in the Twentieth Century. Ithaca: Cornell University Press.

Venter, Albert and Michele Olivier. 1993. "Human Rights in Africa: Nyerere and Kaunda." International Journal on World Peace Vol. 10, No. 1: pages 21-33.

de Vries, Kets. 2004. Lessons on Leadership by Terror: Finding Shaka Zulu in the Attic. Cheltenham: Edward Elgar Publishing Limited. http://dx.doi.org/10.4337/9781845423476

Wills, A. J. 1985. An Introduction to the History of Central Africa: Zambia, Malawi and Zimbabwe. Oxford University Press: Oxford. 
Wriggins, W. Howard. 1969. The Ruler's Imperative: Strategies for Political Survival in Asia and Africa. New York: Columbia University Press.

Zinyama, L.M. 1982. “Post-Independence Land Resettlement in Zimbabwe.” Geography Vol. 67, No. 2: pages 149-52. 